\title{
Attack Assessment Produced by the Major Pests of Roses from Green Areas of Cluj-Napoca
}

\author{
Ion OLTEAN, Cristina SOPORAN, Teodora FLORIAN* \\ Department Environment and Plant Protection. University of Agricultural Sciences and Veterinary \\ Medicine Faculty of Agriculture; \\ * corresponding author: florian.teodora@yahoo.com
}

Bulletin USAMV series Agriculture 72(1)/2015

Print ISSN 1843-5246; Electronic ISSN 1843-5386

DOI 10.15835/buasvmcn-agr: 11157

\begin{abstract}
The most important pests of roses in Cluj area, are Macrosiphum rosae L. Arge rosae, Arge ochropus Gmel., Arge pagan cloth. and Blennocampa pusylla Klug. Populations of these species differ in number density from one location to another. This is determined primarily by the work of care that apply.
\end{abstract}

Keywords: Arge spp., Blennocampa pusylla Klug., Macrosiphum rosae L., monitoring.

\section{INTRODUCTION}

The aesthetic value of an arrangement is given both by its composition in terms of species used and by them health. Pest complex may attack different species of trees, shrubs and herbaceous plants; besides giving an unpleasant aspect of the plant attacked, can cause plants drying off. Roses, particularly popular species in landscaping, are host plants for a rich complex of pests. Of these the most common species are aphids and wasps (Jaukiewicz, 2003; Shaheen and Zaz, 2007).

\section{AIMS}

Identification of the main pests of roses, in Cluj green spaces and assessing the frequency and intensity of attack produced by them in 20122013.

\section{MATERIALS AND METHODS}

From the rose plants biological material was collected for taxonomic identification. Biological material was collected manually by shaking the plants on tarpaulins and evaluation of the frequency of the attack was made by visual inspection of the plant. Species identification was performed in the laboratory of Entomology.

\section{RESULTS}

The most common species that attack roses were the rose aphid, Macrosiphum rosae L. and different species of wasps (Fam. Tenthredinidae and Fam. Argidae). In the monitored location annual average rate of shoots attacked by Macrosiphum rosae L. increased from 13\% in 2011 to $17 \%$ in 2013 . The attack frequency on monitoring sites during three years, ranged from 8\% (U.A.S.V.M. park in 2013) and 31\% (Mărăşti alignment in 2013). On the floral buds Macrosiphum rosae L. caused a frequency of attacks between 6\% (U.A.S.V.M. park in 2012) and 21\% (Mărăşti alignment in 2011) (tab. 1).

From the wasp larvae reported in monitored locations, the most numerous species belonging Arge rosae, followed by Arge ochropus Gmel. and Arge pagan Panz. Frequency of attack produced by the larvae of phytophagous Hymenoptera species ranged from 5\% (U.A.S.V.M. park in 2012) and 21\% (Mărăşti alignment in 2012). Regarding the intensity of the attack, it was between $8 \%$ (U.A.S.V.M. park in 2011) and 15\% (Mărăşti alignment, in 2012 and 2013) (tab.2).

On locations monitored, the frequency of leaves attacked by Blennocampa pusylla Klug. 
Tab. 1. Frequency of young shoots and flower buds attacked by Macrosiphum rosae L. (Cluj-Napoca, 2011-2013)

\begin{tabular}{lcccccc}
\hline & \multicolumn{7}{c}{ Year } \\
\cline { 2 - 7 } Location & \multicolumn{2}{c}{2011} & \multicolumn{2}{c}{2012} & \multicolumn{2}{c}{2013} \\
\cline { 2 - 7 } & $\begin{array}{c}\text { Young } \\
\text { shoots } \\
\%\end{array}$ & $\begin{array}{c}\text { Flower } \\
\text { buds } \\
\%\end{array}$ & $\begin{array}{c}\text { Young } \\
\text { shoots } \\
\%\end{array}$ & $\begin{array}{c}\text { Flower } \\
\text { buds } \\
\%\end{array}$ & $\begin{array}{c}\text { Young } \\
\text { shoots } \\
\%\end{array}$ & $\begin{array}{c}\text { Flower } \\
\text { buds } \\
\%\end{array}$ \\
\hline Mãrãști roundabout & 13 & 11 & 17 & 15 & 18 & 16 \\
\hline Green Zone „Cetățuia“ & 9 & 12 & 12 & 10 & 11 & 8 \\
\hline Mãrãști market alignment & 18 & 21 & 26 & 19 & 31 & 16 \\
\hline Mãnãștur roundabout & 14 & 16 & 15 & 12 & 17 & 10 \\
\hline U.A.S.V.M. park. & 11 & 7 & 9 & 6 & 8 & 7 \\
\hline Average & 13,0 & 13,4 & 15,8 & 12,4 & 17,0 & 11,4 \\
\hline
\end{tabular}

Tab. 2. Frequency (F) and intensity (I) of attack in wasp larvae (Cluj-Napoca, 2011-2013)

\begin{tabular}{lcccccc}
\hline \multirow{2}{*}{ Location } & \multicolumn{7}{c}{ Year } \\
\cline { 2 - 7 } & \multicolumn{2}{c}{2011} & \multicolumn{2}{c}{2012} & \multicolumn{2}{c}{2013} \\
\cline { 2 - 7 } & $\mathrm{F} \%$ & $\mathrm{I} \%$ & $\mathrm{~F} \%$ & $\mathrm{I} \%$ & $\mathrm{~F} \%$ & $\mathrm{I} \%$ \\
\hline Sensul giratoriu Mãrãști & 15 & 10 & 18 & 15 & 13 & 15 \\
\hline Zona verde „Cetăția“ & 11 & 10 & 9 & 13 & 15 & 10 \\
\hline Aliniamentul Piața Mãrãști & 17 & 15 & 21 & 9 & 18 & 14 \\
\hline Sensul giratoriu Mãnãștur & 10 & 8 & 15 & 12 & 9 & 13 \\
\hline Parcul U.S.A.M.V. & 9 & 12 & 5 & 8 & 6 & 9 \\
\hline Average & 12,4 & 11,0 & 13,6 & 11,4 & 12,2 & 12,2 \\
\hline
\end{tabular}

Tab. 3. Frequency of leaves attacked by Blennocampa pusilla Klug. (Cluj-Napoca, 2011-2013)

\begin{tabular}{lccc}
\hline \multirow{2}{*}{ Location } & \multicolumn{3}{c}{ Year } \\
\cline { 2 - 4 } & 2011 & 2012 & 2013 \\
\hline Sensul giratoriu Mãrãști & 8 & 6 & 6 \\
\hline Zona verde „Cetățuia“ & 6 & 4 & 7 \\
\hline Aliniamentul Piața Mãrãști & 10 & 9 & 9 \\
\hline Sensul giratoriu Mãnãștur & 6 & 8 & 7 \\
\hline Parcul U.S.A.M.V. & 2 & 2 & 1 \\
\hline Average & 6,4 & 5,8 & 6,0 \\
\hline
\end{tabular}

was between 1\% (U.A.S.V.M. park, 2013) and 10\% (Mărăşti alignment in 2011) (tab. 3).

\section{CONCLUSION}

Roses complex populations of harmful insects density differ from one location to another. This is determined primarily by the works of care that applies in each location.

\section{REFERENCES}

1. Jaukiewicz B (2003). Dynamika populacji mszyc

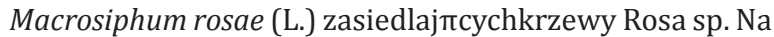
terenach zieleni miejskiej Lublina. Ann. Univ. Mariae Curie Skodowska, Sect. EEE Hort. XIII:271-278.

2. Shaheen G, Zaz GM (2007). Biology of rose aphid Macrosiphum rosae L. (Homoptera: Aphididae) in Kashmir. Applied Biological Research 9:50-53. 